\title{
NIH pledges cash for global protein database
}

Declan Butler, Paris

The United States is turning to European bioinformatics facilities to help it meet its researchers' future needs for databases of protein sequences.

European institutions are set to be the main recipients of a \$15-million, three-year grant from the US National Institutes of Health (NIH), to set up a global database of information on protein sequence and function known as the United Protein Databases, or UniProt.

The NIH is scheduled to announce this week that two-thirds of the grant will go to help maintain two protein databases, SwissProt and Trembl. Swiss-Prot is a curated protein-sequence database that strives to provide a high level of annotation including descriptions of function, structure and variance. Trembl is a computer-annotated supplement to the main database that contains sequences not yet integrated into Swiss-Prot. The two databases were developed by groups at the European Bioinformatics Institute (EBI) near Cambridge in the UK, and the Swiss Institute of Bioinformatics (SIB), which is based at Geneva and Lausanne.

The remainder of the NIH money will support the Protein Information Resource (PIR) database in the United States, which is kept by the Georgetown University Medical Center in Washington DC, and will now merge with its erstwhile European rivals.

"It's the first time that most of the money from such a large, NIH-funded infrastructure project goes outside the United States," says Rolf Apweiler, Swiss-Prot coordinator at the EBI. "This is remarkable, and shows that Americans recognize that the centre of gravity for protein sequence data is in Europe."

Swiss-Prot began life in 1986 as an augmented version of the PIR database. It has grown to be the world's largest protein sequence database, and, according to some researchers, the most useful - for both the quality of additional editorial and functional information that it carries, and the richness of its links to genomic and other bioinformatics databases

The NIH is backing Swiss-Prot because it recognizes that the community is best served by focusing efforts globally on one welldeveloped database, rather than developing a rival, officials close to the decision say.

Under the terms of the grant, PIR will stop maintaining its own database but will assist with the care and feeding of UniProt. Existing data held on PIR will be integrated into Trembl and Swiss-Prot. The grant will enable PIR's organization to remain the same size as it is now, but the funding will allow the EBI and the SIB to expand their protein bioinformatics programmes markedly.

For the biologist at the bench, the move is

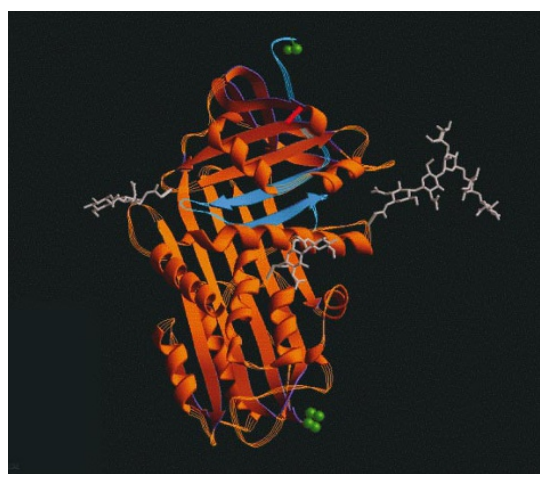

Sound structure: the planned UniProt database will be a valuable resource for protein research.

likely to help guarantee the availability of a sustainable and reliable source of data on protein sequences and functions, as the amount of protein data rapidly expands. Database officials say that the new funding will result in a better quality of curated entries, and more sophisticated tools to help users to navigate the large data sets.

But the news that the NIH is backing the project may create some political embarrassment in Europe, given the notorious reluctance of the European Union to support bioinformatics infrastructure (see Nature 402, 1; 1999).

"It is ironic that the United States gives us money, whereas the European Union seems to expect such infrastructure to live on manna from heaven," says one European expert in biology and information technology. The US investment inevitably also means that the United States will have a greater say in the control of Europe's bioinformatics infrastructure, the expert points out.

\section{EU ponders joint action on cancer}

\section{Sally Goodman, Paris}

Cancer will kill some 750,000 people in the European Union (EU) this year, making it the area's biggest killer after cardiovascular disease. But the EU has no coordinated research approach, and most of its national programmes are small and fragmented.

Researchers, government officials and other interested parties will meet in Brussels on 19 September to try to figure out how this can change. Progress is being slowed, many say, by fragmentation, duplication of effort and a lack of harmonization between EU member states' different programmes.

"We can better tackle the complex and multiple causes of cancer by taking advantage of the diversity in Europe," says Elio Riboli, an epidemiologist at the International Agency for Research on Cancer in Lyons, France, who is running a Europe-wide study of nutrition and lifestyle.

Patterns vary hugely across the continent: deaths from breast cancer in Denmark are much higher than in Portugal, for example, yet three times more Portuguese than Danish men die of stomach cancer.

Researchers face obstacles in setting up Europe-wide clinical trials or exchanging tissue samples. Big differences in training create further barriers to cooperation.

Françoise Meunier, director-general of the Brussels-based European Organisation for Research and Treatment of Cancer, says that the number of multinational clinical trials is limited by the effort required to deal with each country's regulatory, ethical and insurance procedures. "Most clinicians cannot free up enough time," she says.

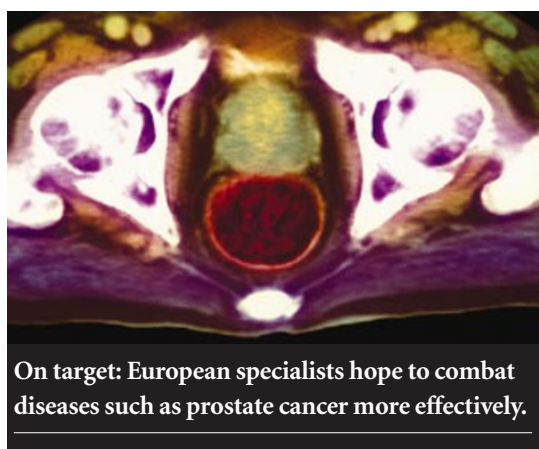

Some nations are trying to restructure their own research. Last year, Britain set up a streamlined National Cancer Research Institute, and the country's two largest cancer charities merged this year (see Nature 416, 474; 2002). On 9 September, the French government set up a commission to plan its national cancer research programme.

Next week's meeting, organized by the European Commission and the European Parliament, will discuss the establishment of a 'European cancer research area', which would help researchers in non-EU countries to work with their EU counterparts. Research commissioner Philippe Busquin has made cancer one of the priorities of the Commission's 2002-06 Framework programme, which allocates $\mathbf{4 0 0}$ million euros (US\$390 million) to cancer research.

But some researchers will tell the meeting that they want to go further and start a truly European cancer initiative. "Cancer is too important to be left to national governments," says Thomas Tursz, director of the Gustave-Roussy Institute in Paris. 